\title{
An Analysis of NPAs in Priority and Non-Priority Sectors with respect to Public Sector Banks in India
}

\author{
Akshay Kumar Mishra ${ }^{1}$

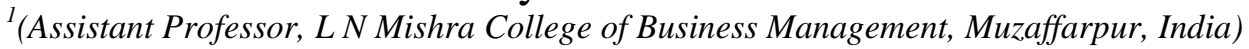

\begin{abstract}
Facilitating loan and advances to customers is the main stream of banking business. The loans are advanced by banking institution to different segment of their market. These segments primarily fall under priority and non-priority sectors, in former sector bank are directed to grant as per guidelines by the Reserve Bank of India. Furthermore, the rise of non-performing assets (NPAs) in banks is influenced by many reasons depending upon the quality of bank's assets in both of these sectors. Many texts suggest that the lending in Priority sector is one of the important causes for the rise of such non performing assets. This paper intended to explore a brief comparison between priority and non-priority sectors NPAs with respect to public sector banks in India based on secondary sources of information.
\end{abstract}

Keywords: banking, loan and advances, non-performing assets, priority sector.

\section{INTRODUCTION}

The bad loans, non performing assets (NPAs) have been creating lots of buzz in the banking sectors throughout their business operation over the years. NPAs are the loans and advances which discontinue fetching the income to the banks i.e. when loan and advances ceases to generate income for the banks and financial institutions are termed as Non-Performing Assets. These assets not only become problem for the banks but also bad for the economy. NPAs lead to affect bank's profitability as well as it increases additional capital needs for recycling of asset and thus deteriorates the quality of assets. In India the banking industry has been witnessed various distinct phases of development. The primary business of banking operation comprises of accepting deposits and further transforming these deposits into large loans to lend it to their customers. These loan and advances granted by the banks are assets which creates income in terms of payment of interest and principal. When these payments become due over the specified period of time becomes bad for the lenders which further classified as Non-Performing as per the banking norm. In line with the international best practices 90 days overdue criteria is used for the classification of NPAs. It has been defined as per the master circular of Reserve Banks of India as the asset including leased assets, when ceases to generate income for the banks becomes NPAs ${ }^{[1]}$. These are the loan and advances, where

- Interest and/or installment of principal remain overdue for more than 90 days in respect of a term loan,

- The account remains out of order for more than 90 days in respect of an overdraft/cash credit,

- The bills remains overdue for more than 90 days in respect of bills purchased and discounted,

- The installment of principal or interest remains overdue for two crop seasons for short duration crops and one crop season for long duration crops,

- The amount of liquidity facility remains outstanding for more than 90 days in respect securitization transaction as per guidelines on securitization dated Feb. 01, 2006,

- The overdue receivables representing positive mark-to-market value of derivative contract, remain unpaid for a period of 90 days from the specified due date for payment in respect of derivative transaction.

Banks are granting advances to various sectors of economy which comprises of both priority and non priority sectors under the RBI's guidelines. The priority sectors include the sectors which require special attention for the development and for the disbursement of adequate credit such as agriculture, education, micro and small enterprise, social infrastructure, renewable energy, housing and others. Sectors other than the priority sectors of economy as above are fall under non-priority sectors. 
Many texts revealed in connection of rising of non-performing assets that the directed lending to priority sector is the most important cause for the same, out of the many internal and external reasons. Non priority sector NPAs is increasing continuously after 2008 in respect of nationalized banks and therefore there is a need to concentrate on this sector to reduce NPAs ${ }^{[2]}$. In 2008, government waived Rs. 60000 crores for farmers and as per the Deputy Governor of RBI, Rs. one lakh crore was sacrificed by the bank for writing off bad loans of corporate in last thirteen years, medium and large enterprises segment has a $50 \%$ share in NPAs ${ }^{[3]}$. This shows that the problematic loan has means from both the sectors of priority and non-priority advances.

\section{REVIEW OF LITERATURE}

Non-Performing Assets has been become a significant concern in the financial sector after the prudential norms for asset classification and income recognition over the years. In relation to non-performing asset management in banks a brief review of literature has been made on the basis of available sources such as Journals, articles, Newspaper, research reports etc. High Non-Performing assets is one of the many problem created by lending to priority sectors along with the problems like low profitability, high transaction cost etc, Uppal (2009) ${ }^{[4]}$. Despite the significance of agriculture in contribution to economy, appropriate credit system has not developed in this connection and the existing system is plagued with increasing NPAs, Baijal (2015) ${ }^{[5]}$. Goyal, Agrawal and Agrawal (2015) concluded that priority sector lending is a major contributor to NPAs in public and private sector banks ${ }^{[6]}$. These studies indicate that there is a significant contribution of priority sector lending towards the NPAs in public sectors banks. In relation to the non-priority sector, there is also a significant relation between both priority and non-priority sector NPAs in contributing to the total NPAs in public sector banks, Nagarajan, Sathyanarayan \& Ali (2014) ${ }^{[7]}$.

\section{RESEARCH METHODOLOGY}

This research study is descriptive in nature. This paper aims to explore a comparison between priority and non-priority sector NPAs in public sector banks in India. The period of study has been selected for 10 years, i.e. from the end of March 2006 to end of March 2015. The data for this study has been used from secondary sources such as RBI's circulars and reports, newspaper, journals and articles etc. The statistical tools such as ratios, correlation and t-test have been used for this study.

\section{PRIORITY SECTOR LENDING}

The banks nationalization were carried out in 1969 by the government to bring banking services to the Indian mass to ensure appropriate credit delivery for the development of the economy. Since then significant measures have been adopted for the purpose of appropriate credit delivery. In this connection, Priority sector lending is playing very significant role for the development. Priority sector which was properly defined in $1972^{[8]}$, are the sectors which require special attention in terms of availability of appropriate credit for development. These are the sectors which may not get timely and adequate credit without special dispensation. Basically the financial assistance under this lending are small value loans to farmers for agriculture and allied activities, micro and small enterprises, poor people for housing, students for education and other low income group and weaker sections ${ }^{[9]}$. As per the Reserve Bank of India (RBI), categories under priority sectors includes Agriculture, Micro, Small and Medium enterprises, Export Credit, Education, Housing, Social Infrastructure, Renewable Energy and others. The targets and sub-targets for priority sector lending are set for the Scheduled Commercial Banks (SCBs) are operating in India are as follows ${ }^{[10]}$.

TABLE I: Targets and Sub-targets for Priority Sectors

\begin{tabular}{|l|l|l|}
\hline Categories & $\begin{array}{l}\text { Domestic SCBs and foreign banks } \\
\text { with 20 branches and above }\end{array}$ & $\begin{array}{l}\text { Foreign banks with less than 20 } \\
\text { branches }\end{array}$ \\
\hline Total Priority Sector & $40 \%$ of Adjusted Net Bank Credit & $40 \%$ of ANBC or credit equivalent \\
\hline
\end{tabular}

Special Issue - AETM'16

$88 \mid$ Page 


\begin{tabular}{|c|c|c|}
\hline & $\begin{array}{l}\text { (ANBC) or credit equivalent amount } \\
\text { of Off-Balance sheet exposure, } \\
\text { whichever is higher }\end{array}$ & $\begin{array}{l}\text { amount of Off-Balance sheet } \\
\text { exposure, whichever is higher; to be } \\
\text { achieved in phased manner by } 2020\end{array}$ \\
\hline Agriculture & $\begin{array}{l}18 \% \text { of Adjusted Net Bank Credit or } \\
\text { credit equivalent amount of Off- } \\
\text { Balance sheet exposure, whichever } \\
\text { is higher }\end{array}$ & Not Applicable \\
\hline Micro Enterprises & $\begin{array}{l}7.5 \% \text { of Adjusted Net Bank Credit } \\
\text { or credit equivalent amount of Off- } \\
\text { Balance sheet exposure, whichever } \\
\text { is higher to be achieved in phased } \\
\text { manner by } 2017\end{array}$ & Not Applicable \\
\hline Advances to weaker sections & $\begin{array}{l}10 \% \text { of Adjusted Net Bank Credit or } \\
\text { credit equivalent amount of Off- } \\
\text { Balance sheet exposure, whichever } \\
\text { is higher to be achieved by foreign } \\
\text { banks in maximum period of five } \\
\text { years from } 2013 \text { to } 2018 \text { as per RBI } \\
\text { guidelines and approval }\end{array}$ & Not Applicable \\
\hline
\end{tabular}

Source Reserve bank of India

On the basis of above insights, it is evident that priority sector lending is major contributor to increase in NPAs in public sector banks; it has a bearing on banks performance. Furthermore, the various sectors of priority have been facilitated adequate financial assistance through banks ${ }^{[11]}$. The public sector banks by providing loan and advances to these sectors, contributed significantly socio economic development of the country ${ }^{[12]}$. Therefore banks should make their efforts to manage and reduce NPAs but not the advances in these sectors.

\section{ANALYSIS AND INTERPRETATION}

Erosion of profits, provisioning and write-off, requirement of additional capital are some major problems created by rising Non Performing Assets (NPAs) in banks. A huge amount of bank's resources are blocked due to rising of such bad loans and thus it becomes unavailable for further lending. As on March $31^{\text {st }}, 2015$ the total amount of NPAs stands at Rs. 2784.68 billion ${ }^{[13]}$ and total of Rs 1.14 lakh crores bad loans have been written off to clean up balance sheet during financial year 2102 to $2015^{[14]}$ in respect of public sector banks in India. The following table shows the level of NPAs in Public Sector Banks for the selected period of study.

TABLE II. Gross advances and NPAs in Public Sector Banks in India Amount in Rs. in billion

\begin{tabular}{|c|c|c|c|}
\hline Year & $\begin{array}{c}\text { Gross } \\
\text { Advances }\end{array}$ & Gross NPAs & $\begin{array}{c}\text { Gross NPA to Gross } \\
\text { Advances (\%) }\end{array}$ \\
\hline 2006 & 11340 & 414 & 3.7 \\
\hline 2007 & 14651 & 389 & 2.7 \\
\hline 2008 & 18191 & 405 & 2.2 \\
\hline 2009 & 22828 & 450 & 2.0 \\
\hline 2010 & 27335 & 599 & 2.2 \\
\hline 2011 & 33465 & 747 & 2.2 \\
\hline 2012 & 39428 & 1173 & 3.0 \\
\hline 2013 & 45601 & 1645 & 3.6 \\
\hline 2014 & 52159 & 2273 & 4.4 \\
\hline
\end{tabular}




\begin{tabular}{|l|l|l|l|}
\hline 2015 & 56167 & 2785 & 5.0 \\
\hline
\end{tabular}

Source: Dept. of Banking supervision, RBI (http://dbie.rbi.org.in/)

The above table shows that ratio of gross NPAs to Gross Advances has been improved from 2006 to 2009, but it has shown increasing pattern continuously form 2012 to 2015, which is a matter of serious concern for the banks. However, the amount of gross NPAs in absolute term has been increased continuously for last 10 years except for financial year ended $31^{\text {st }}$ March, 2007. The following table shows the level of NPAs for last 10 years in priority and non priority sectors.

TABLE III. NPAs in priority and Non Priority Sectors in Public Sector Banks in India

\begin{tabular}{|c|c|c|c|c|c|c|c|}
\hline \multirow{2}{*}{ Year } & \multicolumn{1}{|c|}{ Priority Sector } & \multicolumn{2}{c|}{ Non Priority Sector } & \multicolumn{2}{|c|}{ Public Sector } & \multirow{2}{*}{ Total } \\
\cline { 2 - 7 } & Amount & Ratio (\%) & Amount & Ratio (\%) & Amount & Ratio (\%) & \\
\hline 2006 & 222 & 53.7 & 183 & 44.2 & 9 & 2.1 & 414 \\
\hline 2007 & 225 & 58.0 & 156 & 40.2 & 7 & 1.9 & 389 \\
\hline 2008 & 249 & 61.5 & 150 & 37.1 & 6 & 1.4 & 405 \\
\hline 2009 & 242 & 53.7 & 205 & 45.6 & 3 & 0.7 & 450 \\
\hline 2010 & 305 & 50.9 & 291 & 48.6 & 3 & 0.5 & 599 \\
\hline 2011 & 402 & 53.8 & 342 & 45.9 & 2 & 0.3 & 747 \\
\hline 2012 & 558 & 47.6 & 588 & 50.2 & 27 & 2.3 & 1173 \\
\hline 2013 & 673 & 40.9 & 960 & 58.4 & 12 & 0.7 & 1645 \\
\hline 2014 & 799 & 35.2 & 1472 & 64.8 & 1 & 0.1 & 2273 \\
\hline 2015 & 966 & 34.7 & 1816 & 65.2 & 3 & 0.1 & 2785 \\
\hline
\end{tabular}

Source: Source: Dept. of Banking supervision, RBI (http://dbie.rbi.org.in/)

This table depicts that percentage share of priority sector NPAs is total NPAs have been more than $50 \%$ till March, 2011after that it have decreasing continuously. In case of non-priority sector NPAs, it is increasing continuously in percentage terms from 2011, as on $31^{\text {st }}$ March 2015, it was highest at $65.2 \%$ in the selected period of study. The following chart shows the movement of NPAs in these two sectors.

—Priority Sector NPAs (\%) — Non Priority Sector NPAs (\%)

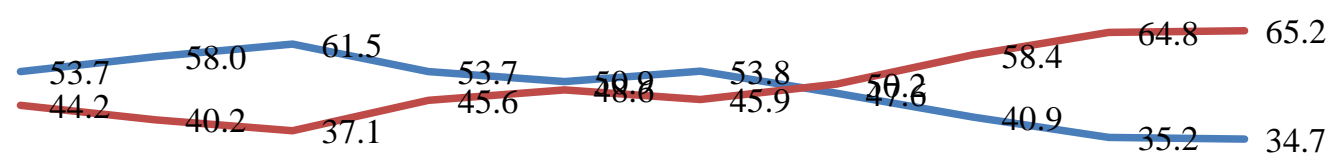

\begin{tabular}{llllllllll}
\hline 2006 & 2007 & 2008 & 2009 & 2010 & 2011 & 2012 & 2013 & 2014 & 2015
\end{tabular}

Chart 1: Ratio (\%) of Priority and Non Priority Sector NPAs of Total NPAs

\subsection{HYPOTHESIS}


The following three hypotheses have been framed to study the significance of priority and non priority sector NAPs in contributing to the total bad loans.

Hypothesis 1

H01: There is no significant relation between Gross Advances to Priority Sector NPAs

H11: There is a significant relation between Gross Advances to Priority Sector NPAs

To test the above hypotheses Pearson Correlation coefficient method and ' $t$-test' (paired two sample for means) have been applied, the results of Pearson correlation coefficient is 0.96659 , which is between +0.75 to +1.0 i.e. there is high degree positive correlation between gross advances and priority sector NPAs.

Mean difference between these two variables is 31652.4, SD (Standard Deviation) $=15574.99, \mathrm{~N}=10$ and df $($ Degree of freedom $)=9, \mathrm{t}$ Stat $(\mathrm{t}$ calculated $)=6.427$ and $\mathrm{P}$ two tail $=0.0001$, confidence interval $=95 \%$, whereas $\mathrm{t}$ critical two tail $=2.2621$, hence null hypothesis is rejected. Therefore it can be found significant relation between gross advances and priority sector NPAs.

Hypothesis 2

H02: There is no significant relation between Gross Advances and Non Priority Sector NPAs

H12: There is a significant relation between Gross Advances and Non Priority Sector NPAs

In this case Pearson Correlation coefficient is 0.921 i.e. highly positive correlation exist between these two variables. A paired sample ' $t$ - test' conducted to test hypothesis, where Mean difference $=31500.20$ and SD $=15283.575, \mathrm{~N}=10, \mathrm{df}=9 \mathrm{t}$ Stat $=6.5175, \mathrm{t}$ critical two tail $=2.2621, \mathrm{P}$ two tail $=0.0001$ at $95 \%$ confidence level. This result suggests that there is a significant relation between Gross advances and Non Priority sector NPAs.

Hypothesis 3

H03: There is no significant relation between Priority sector NPAs and Non Priority Sector NPAs

H13: There is a significant relation between Priority Sector NPAs and Non Priority Sector NPAs

The value of Pearson Correlation coefficient is 0.980 , which suggest that a high degree positive correlation exists between these two sectors of NPAs. Significantly, a paired sample ' $t$ - test' conducted, the value of Mean difference between these two variables is $152.378, \mathrm{SD}=341.285, \mathrm{df}=9, \mathrm{t}$ Stat $=-1.4119, \mathrm{t}$ critical two tail $=2.2621$ and value of $\mathrm{P}$ two tail $=0.192$. This result infers that there is significant relation between Priority and Non Priority Sector NPAs.

\section{CONCLUSION}

It can be concluded that the bad loans create many problems for the banks over the years. Till the March 2011, the contribution of priority sector NPAs were more than $50 \%$ over the years, obviously this become the case with the non priority sectors NPAs after that period. Still these both sectors have significant amount of NPAs, which put tax on the banks overall performance. However the percentage contribution of priority sector NPAs have been decreasing for last couple of years but increasing in absolute terms as bank's total advances are increasing. Similarly non priority sector NPAs are increasing both in percentage contribution to total NPAs as well as in absolute terms. Significantly, on the basis of the insights of the study, it can be concluded that both priority and non priority sector have significant effect on banks NPAs. It can also be concluded that there is a significant relation between priority and non priority sectors NPAs with one another and total NPAs. In spite of the contribution of these sectors in rising bad loans, it is also evident that it contributes to socio economic development as well. Therefore the operating measures of banks and government should make efforts to manage and reduce NPAs along with the facilitation of accelerating this important vehicle of development. 


\section{REFERENCES}

[1] Master Circular - Prudential norms on Income Recognition, Asset Classification and Provisioning pertaining to Advances, 2014.

[2] N. Rani and D. Gaba, 'Analysis of Non-Performing Assets of Public Sector Banks', GJRA- Global Journal for Research Analysis, 3(9), 2014, 5.

[3] M. Shetty, Corporates' Rs 1 lakh crore bad loans written off: RBI, Times of India, 2013.

[4] R K Uppal, "Priority sector advances: Trends, issues and strategy', Journal of Accounting and Taxation, 1(5), $2009,89$.

[5] A.Baijal, "High Ratio of agriculture NPAs in priority sector lending by public and private banks in India- Reasons, suggestions and discussions", International Journal of Science and Research, 4(4), 2015, 885.

[6] N. Goyal, R. Agrawal and R.Agrawal, "A study of effect of priority sector lending (sector wise) on Non Performing Assets of India commercial banks", International Journal of Research in Finance and Marketing, 5(5), 2015, 85.

[7] D. Nagarajan, Sathyanarayan and A. A. Ali, "Non-Performing Asset is a threat to India Banking Sector- A comparative study between priority and non-priority sector lending in public sector banks", International Journal of Advanced research in Management and Social Sciences, 2(11), 2013, 39.

[8] B. Pandya, "Impact of priority sector advances on bank profitability : Evidence from scheduled commercial banks of India", BVIMSR'S Journal of Management Research, 7(2), 2015, 75.

[9] Priority Sector Lending- Targets and classification, RBI, 2014.

[10] Priority Sector Lending- Targets and classification, RBI/2014-15/573 FIDD.COPlan.BC.54/04.09.01/2014-15.

[11] B. Selvarajan and G. Vadivalgan, "A study on management of Non Performing assets in priority sector reference to Indian Bank and Public Sector Banks (PSBs")", International Journal of Finance and Banking Studies IJFBS, 2(1), 2013, 34.

[12] T. N. Sahu and J. K.Nandi, "Social responsibility of selected public and private sector banks in India and its impact on NPA level", Prestige International Journal of Information Technology and Management- Sanchayan, 2, 2013, 65.

[13] Composition of NPAs of Public Sector Banks, RBI.

[14] Rs. 1.14 lakh crores bad loans written off during 2012-15, The Hindu, Feb. 8, 2016, http://www.thehindu.com/business/rs-114-lakh-croresbad-loans-written-off-during-201215/article8209823.ece.

[15] Priority Sector Lending- Targets and classification, RBI/2014-15/573 FIDD.COPlan.BC.54/04.09.01/2014-15, April 23, 2105, RBI.

[16] Composition of NPAs of Public Sector Banks.

[17] Bank- wise and group- wise Gross Non-Performing Assets, Gross Advances and Gross NPA ratio of Scheduled Commercial Banks. 